\title{
A tribute to Professor Sanjaya Lall - a world class industrial development researcher
}

Rasiah Rajah*

Sanjaya Lall, professor of development economics at the University of Oxford died on 18 June 2005. Sanjaya Lall's scholarly credentials were recognized early in his life when he won a gold medal in Patna in 1960, and St. John's College Prize for achieving a first class honours degree at Oxford University in 1963. A prolific development researcher and writer, he eventually published 33 books and hundreds of internationally acclaimed articles. In Sanjaya Lall Oxford University had a truly world class scholar who championed intensely the logic behind why some economies enjoyed higher learning and innovation capabilities than others. To Sanjaya Lall technological capability building was the driver of export competitiveness and growth and hence the path developing economies must take to achieve development. Driven by an epistemological conviction that theory must be defined by evidence, Sanjaya Lall fought an often lonely crusade against the ideologues peddling uncritically, on the one hand, neo-liberalism and, on the other, populism. Unsatisfied with the mainstream economic theory Sanjaya Lall increasingly went to the field to seek empirical ammunition to make sense of the alternative theoretical vision he began to construct to understand the complex problems of development. Sanjaya Lall was less scathing on the partisan populists only because they neither had the power nor the network to influence development policy.

Sanjaya Lall's humility, gentleness and keenness to lead the young selflessly have few peers even among the exceptional scholars. Supremely confident of his abilities and heavily committed to his curious disciples, Sanjaya Lall spent considerable time engaging with promising scholars. His open and inquisitive mind often allowed horizontal dialogues between himself and his students. His brilliance gave him the wit, his artistry gave him the reach, his honesty drove him towards the truth, his selfless character gave him the conviction, his confidence gave him the generosity, his commitment gave him the industry, his diligence made him meticulous and his kindness won him popularity.

Sanjaya Lall had originally made a name in the field of multinationals and developing economies, articulating some of the best explanations of circumstances when linkages will take place and how crowding out can be avoided at host-sites. However, because a number of development pillars interlocked and often influenced the process collectively, Sanjaya Lall began to research and publish on trade and competitiveness, globalization and its economic consequences, industrial policy and industrialization, and innovation and technological capabilities. Although all the above have very much been at the heart of the research many of us have and are still doing, I believe it is in the last area that Sanjaya Lall made most his illuminating contributions to the world of knowledge. Sanjaya Lall found that globalization affected economies differently, benefiting those that enjoyed the technological capabilities (both endowed and created) to compete and draining those that failed to engender them. He was particularly concerned for the Sub-Saharan African economies where increased economic integration into the world economy affected them negatively.

Sanjaya Lall pioneered novel methodologies to demonstrate the importance of technological capabilities through arms-length transactions, and active learning and innovation - for poor economies to move up the development ladder. Consistent with the theoretical logic expounded by Marshall, Tibor Scitovsky and Rosenstein-Rodan, Sanjaya Lall was among the earliest scholars to dismiss the use of the neoclassical production function to estimate spillovers. He had become increasingly concerned with the neo-liberal siege on development economics, what I have begun to call the "mathematics without economic institution syndrome". While he recognized the important contributions mathematics was making in economics, he was concerned

* Professor of Technology and Innovation Policy - Faculty of Economics and Administration, University of Malaysia. E-mail: rajah@ um.edu.my. 50603 Kuala Lumpur Malaysia

Artigo aceito para publicação em novembro de 2004 e aceito em março de 2005. 
over the impact of mathematical economists who neither had the understanding nor the feel for development. Consequently, Sanjaya Lall gradually led a team of young scholars that made incisive strides into measuring technological capabilities, distinguishing different levels of capabilities as firms negotiated the daunting currents of competition to move from price-based competition to product-based competition. The pursuit of novelty and rigour brought him popularity among his admirers, and grudging respect from his critics.

His commitment to assist less developed economies led him to participate directly in the formulation of policies, which made him lead globally influential policy teams (e.g. for UNIDO, UNCTAD and the World Bank) as well as numerous national policy blueprints. While recognizing their power and influence, Sanjaya Lall always insisted on keeping his independence from these global bodies and hence did not join any of them permanently. His reluctance to succumb to orthodox thinking is demonstrated by his refusal to serve the World Bank beyond the periods 1965-68 and 1981-82. In UNCTAD and UNIDO, Sanjaya Lall found two global organizations willing to let him drive policy formulation from the front. He invented several indexes to add strength to the analysis and conclusions to the teams he led in the publication of the World Investment Report. It was unfortunate that some of his own peers turned against him for undertaking work with these organizations. Although saddened that some of his scholarly friends were critical of him, Sanjaya Lall remained committed to changing the policy direction of these organizations. He often said that it is the potential influence his policy work carried, rather than the organization he served, that was important. He would often say that it is everyone's duty to at least make an attempt to change the way these global organizations carried out development advocacy.

The world has lost one of its most potent appropriators of knowledge. His friends will now miss the constant traffic of e-mails and conversations from such a lively, cheerful and engaging scholar. Fortunately for us Sanjaya Lall's inspiring works and the hundreds of prodigies he mentored unselfishly will now carry the torch of development economics for many decades to come. 